CRYSTALLOGRAPHIC COMMUNICATIONS

ISSN 2056-9890

Received 3 August 2020

Accepted 13 August 2020

Edited by J. Ellena, Universidade de Sâo Paulo, Brazil

Keywords: viologen; crystal structure; atropisomer; synthesis.

CCDC reference: 2023167

Supporting information: this article has supporting information at journals.iucr.org/e

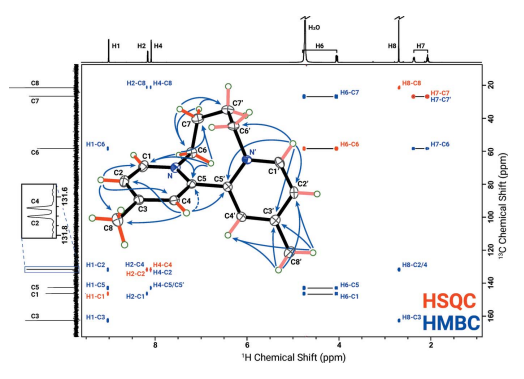

OPEN ӘACCESS

\section{4,15-Dimethyl-7,12-diazoniatricyclo[10.4.0.0 $\left.0^{2,7}\right]$ - hexadeca-1(12),2,4,6,13,15-hexaene dibromide monohydrate}

\author{
Edward J. Behrman, ${ }^{\mathrm{a} *}$ Alexandar L. Hansen, ${ }^{\mathrm{b}}$ Chunhua Yuan ${ }^{\mathrm{b}}$ and Sean Parkin ${ }^{\mathrm{c}}$ \\ a Department of Chemistry \& Biochemistry, The Ohio State University, 484 W. 12th Avenue, Columbus, Ohio, 43210, \\ USA, ${ }^{\mathbf{b}}$ Campus Chemical Instrument Center, The Ohio State University, 496 W. 12th Avenue, Columbus, Ohio, 43210, \\ USA, and ' Department of Chemistry, University of Kentucky, 505 Rose Street, Lexington, Kentucky, 40506, USA. \\ *Correspondence e-mail: behrman.1@osu.edu
}

The title compound, $\mathrm{C}_{16} \mathrm{H}_{20} \mathrm{~N}_{2}{ }^{2+} \cdot 2 \mathrm{Br}^{-} \cdot \mathrm{H}_{2} \mathrm{O}$ (1) is a member of the class of compounds called viologens. Viologens are quaternary salts of dipyridyls and are especially useful as redox indicators as a result of their large negative oneelectron reduction potentials. Compound $\mathbf{1}$ consists of a dication composed of a pair of 4-methylpyridine rings mutually joined at the 2-position, with a dihedral angle between the pyridine rings of $62.35(4)^{\circ}$. In addition, the rings are tethered via the pyridine nitrogen atoms by a tetramethylene bridge. Charge balance is provided by a pair of bromide anions, which are hydrogen bonded to a single water molecule $\left[D_{\mathrm{O} \cdots \mathrm{Br}}=3.3670(15)\right.$ and $\left.3.3856(15) \AA\right]$. The crystal structure of $\mathbf{1}$, details of an improved synthesis, and a full analysis of its NMR spectra are presented.

\section{Chemical context}

The title compound (1) is a member of the class of compounds called viologens. Viologens are quaternary salts of dipyridyls, which have proven useful as redox indicators as a result of their large negative one-electron reduction potentials (Anderson \& Patel, 1984). The herbicides, paraquat, and diquat are viologens. We found that the literature synthesis of 4,4'-dimethyl-2,2'-dipyridyl- $N, N^{\prime}$-tetramethylene dibromide, i.e., 1 (Spotswood \& Tanzer, 1967) could be improved by a change in the solvent. We report details of our improved synthesis of $\mathbf{1}$ along with the crystal structure and a full analysis of its NMR spectra.

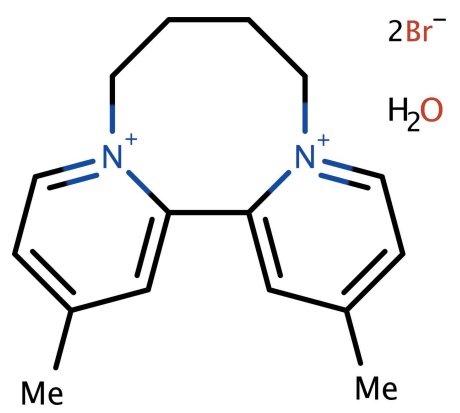

Spotswood \& Tanzer (1967) give general directions for the syntheses of a series of bridged dimethyl 2,2'-dipyridyl salts. Our attempts to make the title compound by their directions failed; only a salt of the starting dipyridyl was recovered. Homer \& Tomlinson (1960) noted that $\mathrm{HBr}$ is formed by dehydrohalogenation of the dibromide. We think that the conditions used by Anderson \& Patel (1984), i.e., refluxing 


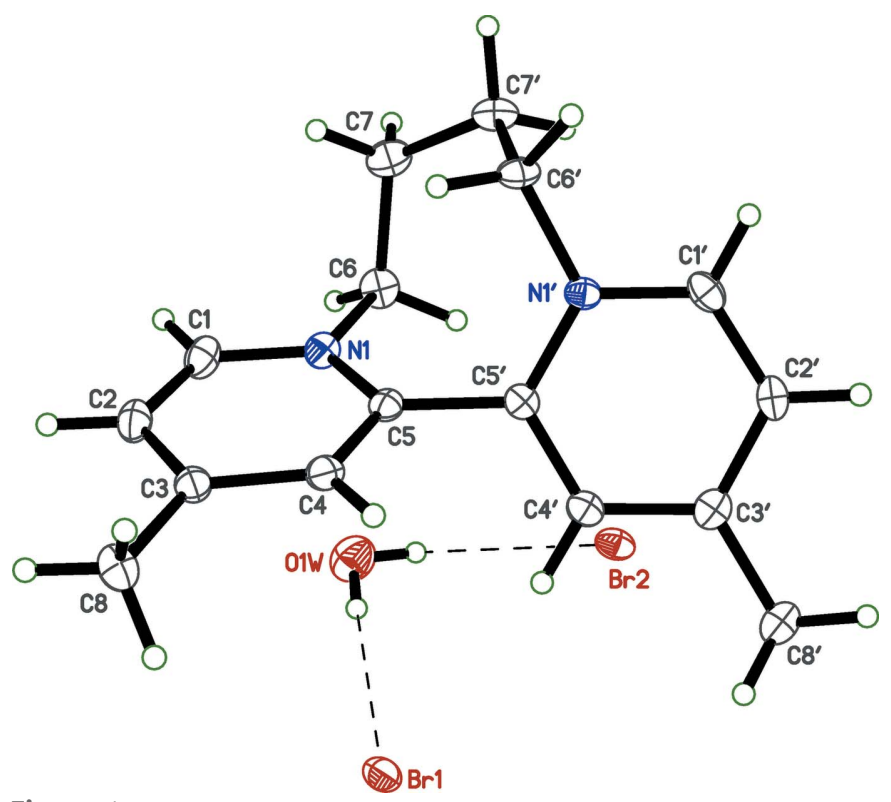

Figure 1

A view of $\mathbf{1}$ showing the atom-labeling scheme. Displacement ellipsoids are drawn at the $50 \%$ probability level. Hydrogen bonds between water and $\mathrm{Br}^{-}$are shown as dashed lines.

$o$-dichlorobenzene, b.p. $453 \mathrm{~K}$, produced a good deal of $\mathrm{HBr}$, which protonated the dipyridyl, rendering it unreactive. Carrying out the reaction in refluxing xylene (mixed isomers, b.p. $c a 413 \mathrm{~K}$ ) does not produce $\mathrm{HBr}$, but the reaction is slow; after five h, about $50 \%$ of the starting dipyridyl was recovered. The quaternization of tertiary amines is known as the Menschutkin reaction (Menschutkin, 1890). The velocity of this reaction shows a strong dependence on solvent (Abraham
\& Grellier, 1976), with about a 65,000-fold increase from hexane to DMSO. The addition of nitrobenzene to the solvent gave satisfactory yields of the product in a reasonable time (see Synthesis and crystallization section).

\section{Structural commentary}

The molecular structure of $\mathbf{1}$ is shown in Fig. 1. It consists of a dication composed of a pair of 4-methylpyridine rings mutually joined at their 2-positions, with a dihedral angle between the pyridine rings of 62.35 (4) ${ }^{\circ}$. In addition, the rings are tethered via the pyridine nitrogen atoms by a tetramethylene bridge. There are no unusual bond lengths or angles. As a result of the two bridges between the pyridine rings, 1 occurs as two optical isomers, and therefore provides an example of atropisomerism (Eliel et al., 1994; Alkorta et al., 2012; Mancinelli et al., 2020). Crystals of 1, however, were centrosymmetric, with space group $P 2_{1} / n$, and are thus strictly racemic. Charge balance is provided by a pair of bromide anions, which are hydrogen bonded to a single water molecule of crystallization $\left[D_{\mathrm{O} \cdots \mathrm{Br}}=3.3670(15)\right.$ and $\left.3.3856(15) \AA\right]$ (Table 1).

\section{Supramolecular features}

Aside from the hydrogen bonds between the water molecule and bromide anions, the only other notable intermolecular contacts are interactions of type $\mathrm{C}-\mathrm{H} \cdots \mathrm{Br}$ (Fig. 2, Table 1), with distances that range between $3.5765(17)$ and $3.7762(18) \AA$ for type $\mathrm{C}_{\text {pyridyl }} \cdots \mathrm{Br}$ and 3.6581 (18) to 3.7700 (19) $\AA$ for type $\mathrm{C}_{\text {methylene }} \cdots \mathrm{Br}$. For comparison, the

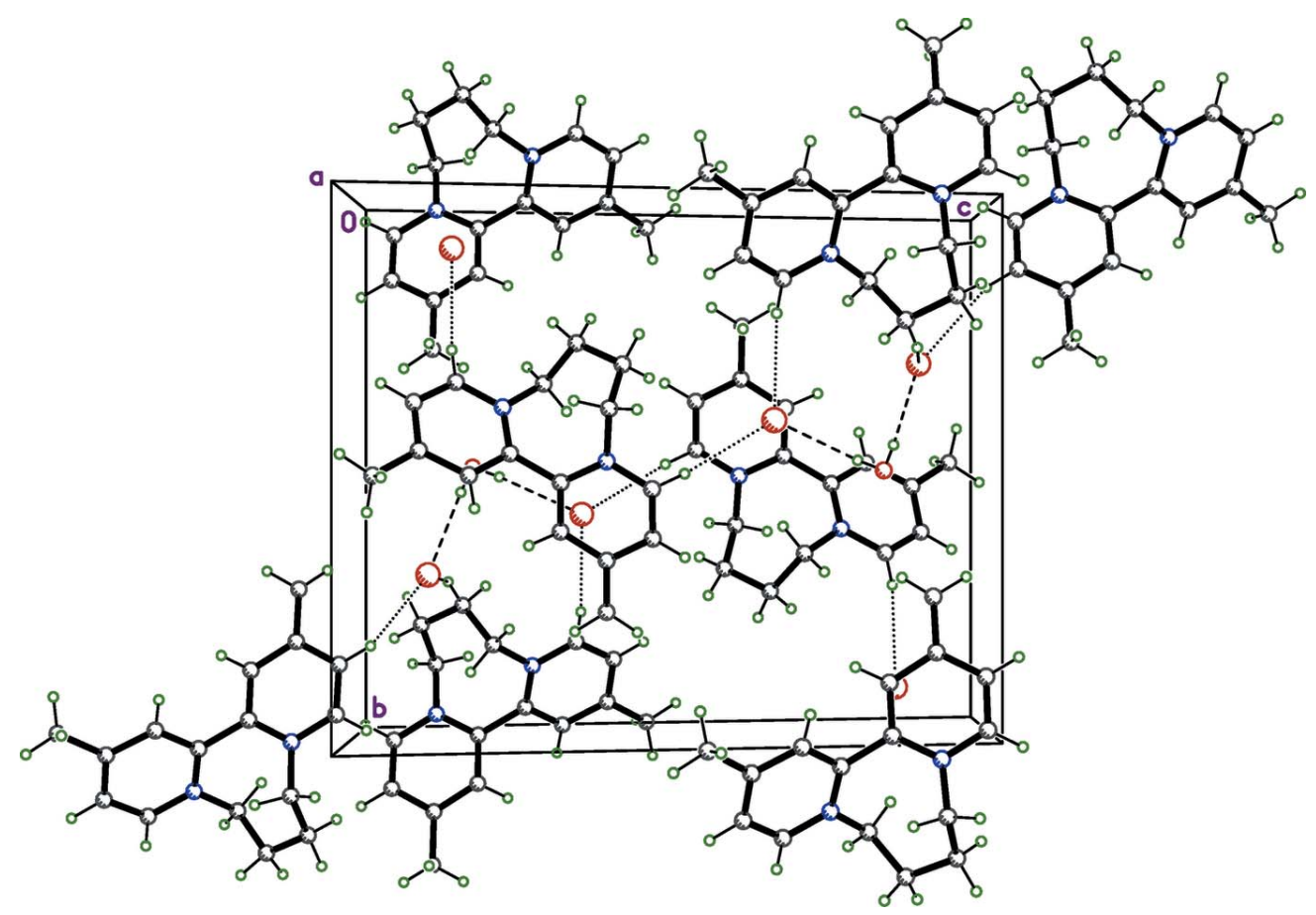

Figure 2

A packing plot of $\mathbf{1}$ viewed down the crystallographic $a$ axis. Hydrogen bonds between water and $\mathrm{Br}^{-}$are shown as dashed lines, while weaker $\mathrm{C}-$ $\mathrm{H} \cdots \mathrm{Br}$ interactions are shown as dotted lines. 
Table 1

Hydrogen-bond geometry $\left(\AA,^{\circ}\right)$.

\begin{tabular}{lllll}
\hline$D-\mathrm{H} \cdots A$ & $D-\mathrm{H}$ & $\mathrm{H} \cdots A$ & $D \cdots A$ & $D-\mathrm{H} \cdots A$ \\
\hline $\mathrm{C} 1-\mathrm{H} 1 \cdots \mathrm{Br} 2^{\mathrm{i}}$ & 0.95 & 2.68 & $3.5929(18)$ & 161 \\
$\mathrm{C} 2-\mathrm{H} 2 \cdots \mathrm{Br} 1^{\mathrm{ii}}$ & 0.95 & 2.86 & $3.7762(18)$ & 161 \\
$\mathrm{C} 7-\mathrm{H} 7 B \cdots \mathrm{Br} 1^{\mathrm{i}}$ & 0.99 & 2.96 & $3.7700(19)$ & 139 \\
$\mathrm{C}^{\prime}-\mathrm{H} 1^{\prime} \cdots \mathrm{Br} 2^{\mathrm{iii}}$ & 0.95 & 2.64 & $3.5765(17)$ & 170 \\
$\mathrm{C}^{\prime}-\mathrm{H} 2^{\prime} \cdots \mathrm{Br} 1^{\text {iv }}$ & 0.95 & 2.82 & $3.6285(17)$ & 143 \\
$\mathrm{C}^{\prime}-\mathrm{H} 4^{\prime} \cdots \mathrm{Br} 1$ & 0.95 & 2.74 & $3.6735(17)$ & 167 \\
$\mathrm{C} 7^{\prime}-\mathrm{H} 7 B^{\prime} \cdots \mathrm{Br} 1^{\mathrm{v}}$ & 0.99 & 3.04 & $3.6581(18)$ & 122 \\
$\mathrm{O} 1 W-\mathrm{H} 1 W \cdots \mathrm{Br} 1$ & $0.81(2)$ & $2.58(2)$ & $3.3856(15)$ & $177(3)$ \\
$\mathrm{O} 1 W-\mathrm{H} 2 W \cdots \mathrm{Br} 2$ & $0.81(2)$ & $2.56(2)$ & $3.3670(15)$ & $175(3)$ \\
\hline
\end{tabular}

Symmetry codes: (i) $\quad-x+\frac{1}{2}, y-\frac{1}{2},-z+\frac{1}{2}$; (ii) $\quad-x+1,-y+1,-z$; $\quad$ (iii) $-x+1,-y+1,-z+1$; (iv) $x+\frac{1}{2},-y+\frac{3}{2}, z+\frac{1}{2}$; (v) $-x+\frac{3}{2}, y-\frac{1}{2},-z+\frac{1}{2}$.

Table 2

Percentage of atom $\cdots$ atom contacts between asymmetric units in $\mathbf{1}$.

\begin{tabular}{ll}
\hline $\mathrm{H} \cdots \mathrm{H}$ & 57.0 \\
$\mathrm{H} \cdots \mathrm{Br}$ & 26.2 \\
$\mathrm{H} \cdots \mathrm{C}$ & 9.0 \\
$\mathrm{H} \cdots \mathrm{O}$ & 4.7 \\
$\mathrm{C} \cdots \mathrm{Br}$ & 1.7 \\
$\mathrm{~N} \cdots \mathrm{Br}$ & 1.1 \\
$\mathrm{C} \cdots \mathrm{C}$ & 0.4 \\
$\mathrm{~N} \cdots \mathrm{N}$ & 0.0 \\
$\mathrm{O} \cdots \mathrm{O}$ & 0.0 \\
$\mathrm{Br} \cdots \mathrm{Br}$ & 0.0 \\
\hline
\end{tabular}

Contact percentages were derived from Hirshfeld-surface fingerprint plots (Spackman \& McKinnon, 2002; McKinnon et al., 2004) using CrystalExplorer 17.5 (Turner et al., 2017). Reciprocal contacts are included in the totals. The sum of all percentages in the table is $100.1 \%$ due to accumulation of rounding errors.

standard van der Waals radii of $\mathrm{C}, \mathrm{H}$, and $\mathrm{Br}$ (Bondi, 1964) are $1.2,1.7$, and $1.85 \AA$, respectively. The percentages of atom ...atom contact types between asymmetric units were obtained from Hirshfeld-surface fingerprint plots (Figs. S1 and S2 in the supporting information; Spackman \& McKinnon, 2002; McKinnon et al., 2004) using CrystalExplorer 17.5 (Turner et al., 2017), and are presented in Table 2.

\section{Database survey}

The most similar structures to $\mathbf{1}$ in the Cambridge Structural Database (CSD, V5.41, update of November 2019; Groom et $a l ., 2016)$ are BIYTEL, BIYTUB, BIYTOV, BIYVAJ, and BIYTIP (Sanchez et al., 2019). BIYTEL has a trimethylene bridge, BIYTUB has a dimethylene bridge, BIYTOV has a trimethylene bridge but lacks the 4-Me substituents, BIYVAJ has a trimethylene bridge but 5-Me groups instead of 4-Me, and BIYTIP has a dimethylene bridge but is a methanol solvate. CSD entry TMEPYR (Derry \& Hamor, 1970) contains a tetramethylene bridge, but lacks 4-Me subsituents. CSD entries DIQUAT (Derry \& Hamor, 1969) and DQUATB (Sullivan \& Williams, 1976), have dimethylene bridges but also lack the 4-Me substituents. Atomic coordinates for TMEPYR, DIQUAT and DQUATB are, however, not present in the CSD. CSD entry PICGAM (Talele et al., 2018) has a $-\mathrm{CH}_{2} \mathrm{C}_{6} \mathrm{H}_{4} \mathrm{CH}_{2}-$ linker and is an acetonitrile solvate. These crystal structures have $\mathrm{Br}^{-}$anions for charge balance and (unless otherwise stated) include water of crystallization. The tetramethylene bridge is present in CSD entries HIJGAI (Hofbauer et al., 1996), YOBWAN (Schmauch et al., 1995), and YUFCOR (Knoch et al., 1995), but these crystal structures feature complex organometallic anions rather than bromide and are not hydrates. The dihedral angle between the two pyridine rings in each structure is strongly dependent on the length of the bridging tether. These range between 15.78$19.01^{\circ}$ for dimethylene, $49.40-53.96^{\circ}$ for trimethylene, and $63.87-67.15^{\circ}$ for tetramethylene $\left[c f .62 .35(4)^{\circ}\right.$ in 1 $]$. In PICGAM, the dihedral angle is $72.64^{\circ}$, presumably as a result of the increased rigidity of the tether.

\section{NMR spectroscopic analysis}

The low-field NMR spectrum has been well analyzed by Spotswood \& Tanzer (1967), with whose data we agree. However, the instruments available in 1967 were not able to resolve the bridge protons. Thummel et al. (1985) reported data on the bipyridyl analog, that is, without the 4,4'-methyl groups. Our data closely match theirs (see especially Fig. 3 of Thummel et al., 1985), showing an identical complex splitting pattern for the four resolved signals. The protons of the

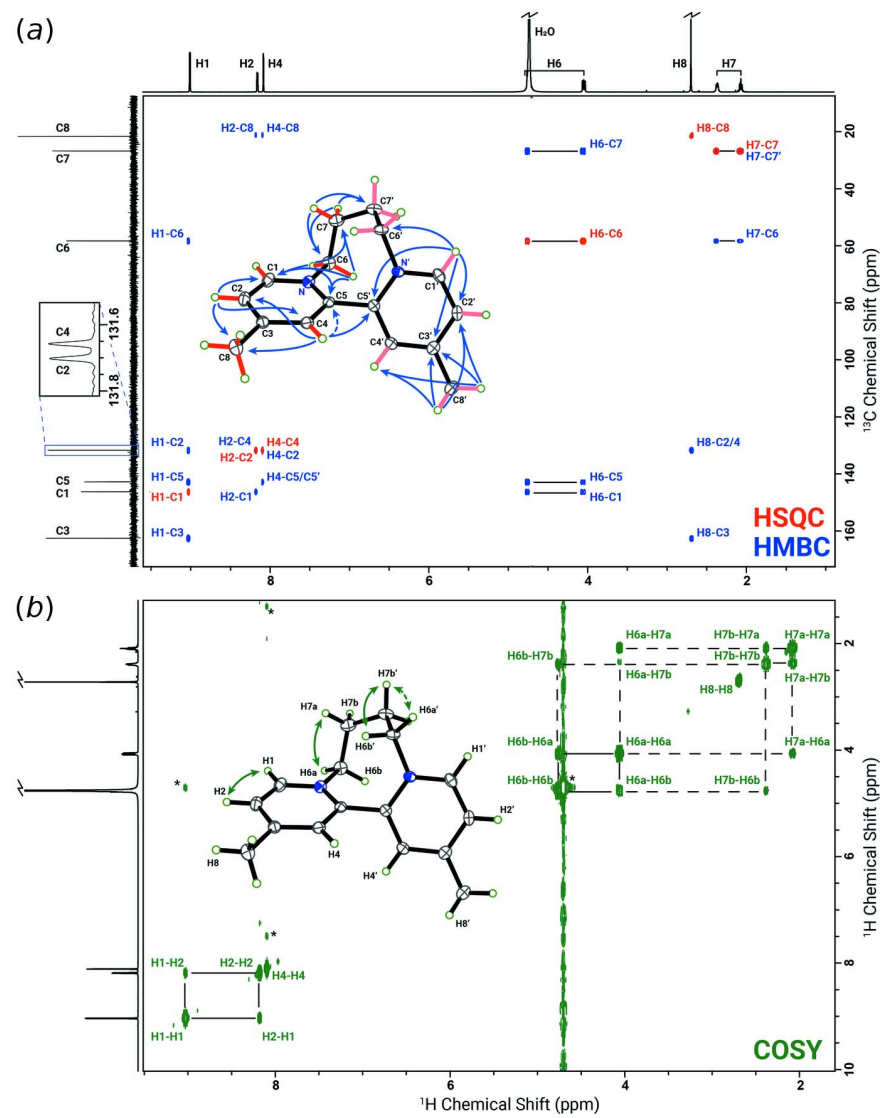

Figure 3

Analysis of 2-D NMR spectra: (a) HSQC and HMBC resonance assignments, $(b)$ COSY resonance assignments. Peaks marked by an asterisk correspond to water or multiple quantum artifacts. 1-D traces are shown to the left and top of the figure. 
Table 3

${ }^{1} \mathrm{H}$ and ${ }^{13} \mathrm{C}$ NMR spectroscopic data for $\mathbf{1}$ recorded in $\mathrm{D}_{2} \mathrm{O}$ at $298 \mathrm{~K}$.

\begin{tabular}{llll}
\hline Assignments & ${ }^{13} \mathrm{C}(\mathrm{ppm})$ & ${ }^{1} \mathrm{H}(\mathrm{ppm})$ & Couplings $(\mathrm{Hz})$ \\
\hline $\mathrm{C}^{1} / \mathrm{H}^{1}$ & 146.25 & 8.99 & ${ }^{3} J\left(\mathrm{H}^{1} \mathrm{H}^{2}\right) 6.4$ \\
$\mathrm{C}^{2} / \mathrm{H}^{2}$ & 131.70 & 8.14 & \\
$\mathrm{C}^{3}$ & 162.63 & & \\
$\mathrm{C}^{4} / \mathrm{H}^{4}$ & 131.66 & 8.07 & \\
$\mathrm{C}^{5}$ & 142.78 & & \\
$\mathrm{C}^{6} / \mathrm{H}^{6 A}, \mathrm{H}^{6 B}$ & 58.26 & $\mathrm{H}^{6 A, 6 B} 4.73,4.03$ & \\
$\mathrm{C}^{7} / \mathrm{H}^{7 A}, \mathrm{H}^{7 B}$ & 26.72 & $\mathrm{H}^{7 A, 7 B} 2.35,2.05$ & ${ }^{2} J\left(\mathrm{H}^{6 a} \mathrm{H}^{7 A} \mathrm{H}^{6 B}\right) 14.5,{ }^{3} J\left(\mathrm{H}^{6 A}\right) 11.1$ \\
$\mathrm{C}^{8} / \mathrm{H}^{8}$ & 2.68 & \\
$\mathrm{~N}^{9}$ & 21.62 & & \\
\hline
\end{tabular}

The errors were estimated to be $\pm 0.02 \mathrm{ppm}, \pm 0.002 \mathrm{ppm}$, and $\pm 0.3 \mathrm{~Hz}$, respectively, for the ${ }^{13} \mathrm{C}$ chemical shifts, ${ }^{1} \mathrm{H}$ chemical shifts, and $J$ coupling constants.

methyl group exchange with deuterons in a base-catalyzed reaction (Zoltewicz \& Jacobson, 1978). Our NMR sample, which also showed exchange, was neutral. Exchange was prevented by adjusting the ' $\mathrm{pH}$ ' to $\sim 1$ with $\mathrm{DCl}$. This exchange with solvent deuterium led to some deuterium couplings with both protons and carbon and hence multiplicities in the NMR spectra, which were initially puzzling. Calder et al. (1967) discuss the effect of the length of the bridging group on the NMR spectra and the mobility of the structures.

There are eight resonance signals in the ${ }^{1} \mathrm{H}$ NMR spectrum recorded in $\mathrm{D}_{2} \mathrm{O}$, including one on the downfield shoulder of the residual water resonance. All but one of the signals are of equal intensity and the one at $2.68 \mathrm{ppm}$ is about three times larger. The ${ }^{13} \mathrm{C}$ NMR spectrum shows eight signals $(\mathrm{C} 1-\mathrm{C} 8)$, two of which (C2 and $\mathrm{C} 4)$ are barely separated. Quantitative measurement using inverse-gated decoupling with a long recycle delay ( $60 \mathrm{~s}$ ) shows that the carbon signals are of equal intensity. The 1-D ${ }^{13} \mathrm{C}$ DEPT (Distortionless Enhancement by Polarization Transfer) and 2-D multiplicity-edited ${ }^{1} \mathrm{H}-{ }^{13} \mathrm{C}$ HSQC (Heteronuclear Single Quantum Coherence) establish a ratio of 3:2:1 for $\mathrm{CH}, \mathrm{CH}_{2}$, and $\mathrm{CH}_{3}$, respectively. Further analysis of 2-D ${ }^{1} \mathrm{H}$ COSY (Correlation Spectroscopy) and 2-D ${ }^{1} \mathrm{H}-{ }^{13} \mathrm{C}$ HMBC (Heteronuclear Multiple-Bond Correlation spectroscopy) spectra led to the NMR assignments summarized in Table 3. A selective HMBC focusing on the $\mathrm{C} 2 / \mathrm{C} 4$ region was recorded for unambiguous assignments of multiple-bond ${ }^{1} \mathrm{H}-{ }^{13} \mathrm{C}$ correlations related to these two carbons. These details together with the 2-D ${ }^{1} \mathrm{H}-{ }^{15} \mathrm{~N}$ HMBC, which reveals stronger $\mathrm{H} 2 / \mathrm{N} 9$ and $\mathrm{H} 4 / \mathrm{N} 9$ cross-peaks than $\mathrm{H} 1 /$ $\mathrm{N} 9$, clearly establish a symmetric three-ring molecular structure, as shown in Fig. 3, in full agreement with the crystal structure (Fig. 1).

The stereospecific assignment of the methylene protons was achieved by a systematic recording of 1-D selective NOESY (Nuclear Overhauser Effect Spectroscopy) and COSY spectra. A stronger NOE was observed between the proton at $4.73 \mathrm{ppm}$ and $\mathrm{H} 1$, and thus this resonance was assigned to $\mathrm{H} 6 A$ while the geminal one at $4.03 \mathrm{ppm}$ to $\mathrm{H} 6 B$. The 1-D selective homonuclear decoupling ${ }^{1} \mathrm{H}$ NMR spectra led to the extraction of $J$-coupling constants between these methylene protons (Table 3$)$. A large ${ }^{3} J$ coupling exists between $\mathrm{H} 6 B$ and $\mathrm{H} 7 B(11.3 \mathrm{~Hz})$, followed by a sizable ${ }^{3} J$ coupling between $\mathrm{H} 6 A$ and $\mathrm{H} 7 A(6.1 \mathrm{~Hz})$. As a result of the complexity of the spectra, the ${ }^{3} J\left(\mathrm{H}^{6 A} \mathrm{H}^{7 B}\right)$ and ${ }^{3} J\left(\mathrm{H}^{6 B} \mathrm{H}^{7 A}\right)$ could not be determined, but were estimated to be less than $2 \mathrm{~Hz}$. Also, the $11.1 \mathrm{~Hz}$ coupling between $\mathrm{H} 7 A$ and $\mathrm{H} 7 B$ was tentatively assigned to the geminal coupling rather than the one across the $\mathrm{C} 7-\mathrm{C}^{\prime}$ bond.

All NMR spectra were recorded on a Bruker Ascend $700 \mathrm{MHz}$ spectrometer equipped with a TXO cryoprobe at 298 K. Spectra were indirectly referenced to the deuterium lock frequency, set to $4.7 \mathrm{ppm}$.

\section{Synthesis and crystallization}

The starting materials were standard commercial samples of 95-98\% purity. 4,4'-Dimethyl-2,2'-dipyridyl (0.92 g, $5 \mathrm{mmol}$ ) and 1,4-dibromobutane $(0.6 \mathrm{~mL}, 1.08 \mathrm{~g}, 5 \mathrm{mmol})$ were added to a mixture of $5 \mathrm{~mL}$ each of xylene (mixed isomers, b.p. $c a$ $413 \mathrm{~K}$ ) and nitrobenzene (b.p. $483 \mathrm{~K}$ ). The mixture was refluxed for about $5 \mathrm{~h}$, during which time a heavy precipitate formed. After cooling, the crude material was filtered and washed with acetone to yield $1.1 \mathrm{~g}$ of a tan-colored powder. Paper electrophoresis of this material at $\mathrm{pH} 7.5$ showed (via UV) a small amount of starting material at $R_{p} c a$ zero and product at $R_{p}-2.2$ ( $R_{p}$ is movement relative to picric acid). Crystallization from methanol-acetone gave $0.5-0.6 \mathrm{~g}$ (ca $50 \%$ ) of reddish crystals, m.p. 528-530 K [lit. 528-533 K; Spotswood \& Tanzer (1967)], $\mathrm{UV}_{\max }$ (water) $271 \mathrm{~nm}$. IR(Nujol): 3456, 3414, 3372, 1632, 1582, 1566, 1514 1312, 1159, $1032,853 \mathrm{~cm}^{-1}$.

\section{Refinement}

Crystal data, data collection and structure refinement details are summarized in Table 4. All hydrogen atoms were found in difference-Fourier maps. Those attached to carbon were subsequently included in the refinement using riding models, with constrained distances set to $0.95 \AA\left(\mathrm{Csp}^{2} \mathrm{H}\right), 0.98 \AA$ $\left(R \mathrm{CH}_{3}\right)$, and $0.99 \AA\left(R_{2} \mathrm{CH}_{2}\right)$. Water hydrogen coordinates were refined, but subject to a restraint on the $\mathrm{O}-\mathrm{H}$ distances (SHELXL command SADI). $U_{\text {iso }}(\mathrm{H})$ parameters were set to values of either $1.2 U_{\mathrm{eq}}$ or $1.5 U_{\mathrm{eq}}\left(R \mathrm{CH}_{3}\right.$ only) of the attached atom. 
Table 4

Experimental details.

\begin{tabular}{|c|c|}
\hline \multicolumn{2}{|l|}{ Crystal data } \\
\hline Chemical formula & $\mathrm{C}_{16} \mathrm{H}_{20} \mathrm{~N}_{2}^{2+} \cdot 2\left(\mathrm{Br}^{-}\right) \cdot \mathrm{H}_{2} \mathrm{O}$ \\
\hline$M_{\mathrm{r}}$ & 418.17 \\
\hline Crystal system, space group & Monoclinic, $P 2_{1} / n$ \\
\hline Temperature $(\mathrm{K})$ & 90 \\
\hline$a, b, c(\AA)$ & $7.6402(2), 13.7578(3), 16.7691(3)$ \\
\hline$\beta\left(^{\circ}\right)$ & $101.162(1)$ \\
\hline$V\left(\AA^{3}\right)$ & $1729.30(7)$ \\
\hline$Z$ & 4 \\
\hline Radiation type & Mo $K \alpha$ \\
\hline$\mu\left(\mathrm{mm}^{-1}\right)$ & 4.69 \\
\hline Crystal size (mm) & $0.16 \times 0.12 \times 0.07$ \\
\hline \multicolumn{2}{|l|}{ Data collection } \\
\hline Diffractometer & Bruker D8 Venture dual source \\
\hline Absorption correction & $\begin{array}{l}\text { Multi-scan (SADABS; Krause et } \\
\quad \text { al., 2015) }\end{array}$ \\
\hline$T_{\min }, T_{\max }$ & $0.562,0.746$ \\
\hline $\begin{array}{l}\text { No. of measured, independent and } \\
\text { observed }[I>2 \sigma(I)] \text { reflections }\end{array}$ & $26025,3959,3527$ \\
\hline$R_{\text {int }}$ & 0.029 \\
\hline$(\sin \theta / \lambda)_{\max }\left(\AA^{-1}\right)$ & 0.650 \\
\hline \multicolumn{2}{|l|}{ Refinement } \\
\hline$R\left[F^{2}>2 \sigma\left(F^{2}\right)\right], w R\left(F^{2}\right), S$ & $0.020,0.043,1.06$ \\
\hline No. of reflections & 3959 \\
\hline No. of parameters & 198 \\
\hline No. of restraints & 1 \\
\hline $\mathrm{H}$-atom treatment & $\begin{array}{l}\mathrm{H} \text { atoms treated by a mixture of } \\
\text { independent and constrained } \\
\text { refinement }\end{array}$ \\
\hline$\Delta \rho_{\max }, \Delta \rho_{\min }\left(\mathrm{e} \AA^{-3}\right)$ & $0.38,-0.38$ \\
\hline
\end{tabular}

Computer programs: APEX3 (Bruker, 2016), SHELXT (Sheldrick, 2015a), SHELXL2018/3 (Sheldrick, 2015b), XP in SHELXTL (Sheldrick, 2008), SHELX (Sheldrick, 2008), CIFFIX (Parkin, 2013), and publCIF (Westrip, 2010).

\section{Acknowledgements}

The D8 Venture diffractometer was funded by the NSF (MRI CHE1625732), and by the University of Kentucky.

\section{Funding information}

Funding for this research was provided by: NSF (grant No. CHE1625732 to Sean Parkin).

\section{References}

Abraham, M. H. \& Grellier, P. L. (1976). J. Chem. Soc. Perkin II 1735-1741.
Alkorta, I., Elguero, J., Roussel, C., Vanthunyne, N. \& Piras, P. (2012). Adv. Heterocycl. Chem., 105, 1-188.

Anderson, R. F. \& Patel, K. B. (1984). J. Chem. Soc. Faraday Trans. 1, 80, 2693-2702.

Bondi, A. (1964). J. Phys. Chem. 68, 441-451.

Bruker (2016). APEX3 Bruker AXS Inc., Madison, Wisconsin, USA.

Calder, I. C., Spotswood, M. \& Tanzer, C. I. (1967). Aust. J. Chem. 20, $1195-1212$.

Derry, J. E. \& Hamor, T. A. (1969). Nature, 221, 464-465.

Derry, J. E. \& Hamor, T. A. (1970). J. Chem. Soc. D, pp. 12841286.

Eliel, E. L., Wilen, S. H. \& Mander, L. N. (1994). Stereochemistry of Organic Compounds. New York: Wiley.

Groom, C. R., Bruno, I. J., Lightfoot, M. P. \& Ward, S. C. (2016). Acta Cryst. B72, 171-179.

Hofbauer, M., Möbius, M., Knoch, F. \& Benedix, R. (1996). Inorg. Chim. Acta, 247, 147-154.

Homer, R. F. \& Tomlinson, T. E. (1960). J. Chem. Soc. pp. $2498-$ 2503.

Knoch, F., Schmauch, G. \& Kisch, H. (1995). Z. Kristallogr., 210, 7677.

Krause, L., Herbst-Irmer, R., Sheldrick, G. M. \& Stalke, D. (2015). J. Appl. Cryst. 48, 3-10.

Mancinelli, M., Bencivenni, G., Pecorari, D. \& Mazzanti, A. (2020). Eur. J. Org. Chem. 2020, 4070-4086.

McKinnon, J. J., Spackman, M. A. \& Mitchell, A. S. (2004). Acta Cryst. B60, 627-668.

Menschutkin, N. (1890). Z. Physik. Chem. 5, 589-600.

Parkin, S. (2013). CIFFIX, https://xray.uky.edu/Resources/scripts/ ciffix

Sanchez, M. L. K., Wu, C. H., Adams, M. W. W. \& Dyer, R. B. (2019). Chem. Commun. 55, 5579-5582.

Schmauch, G., Knoch, F. \& Kisch, H. (1995). Chem. Ber. 128, 303-307.

Sheldrick, G. M. (2008). Acta Cryst. A64, 112-122.

Sheldrick, G. M. (2015a). Acta Cryst. A71, 3-8.

Sheldrick, G. M. (2015b). Acta Cryst. C71, 3-8.

Spackman, M. A. \& McKinnon, J. J. (2002). CrystEngComm, 4, 378392.

Spotswood, T. M. \& Tanzer, C. I. (1967). Aust. J. Chem. 20, 1213-1225.

Sullivan, P. D. \& Williams, M. L. (1976). J. Am. Chem. Soc. 98, 17111716.

Talele, H. R., Koval, D., Severa, L., Reyes-Gutiérrez, P. E., Císařová, I., Sázelová, P., Šaman, D., Bednárová, L., Kašička, V. \& Teplý, F. (2018). Chem. Eur. J. 24, 7601-7604.

Thummel, R. P., Lefoulon, F. \& Mahadevan, R. (1985). J. Org. Chem. 50, 3824-3828.

Turner, M.J., Mckinnon, J.J., Wolff, S.K., Grimwood, D.J., Spackman, P.R., Jayatilaka, D. \& Spackman, M.A. (2017). Crystal Explorer 17.5. The University of Western Australia.

Westrip, S. P. (2010). J. Appl. Cryst. 43, 920-925.

Zoltewicz, J. A. \& Jacobson, H. L. (1978). J. Org. Chem. 43, 19-23. 


\section{supporting information}

Acta Cryst. (2020). E76, 1467-1471 [https://doi.org/10.1107/S2056989020011147]

\section{4,15-Dimethyl-7,12-diazoniatricyclo[10.4.0.0 $\left.{ }^{2,7}\right]$ hexadeca-1(12),2,4,6,13,15- hexaene dibromide monohydrate}

\section{Edward J. Behrman, Alexandar L. Hansen, Chunhua Yuan and Sean Parkin}

Computing details

Data collection: APEX3 (Bruker, 2016); cell refinement: APEX3 (Bruker, 2016); data reduction: APEX3 (Bruker, 2016); program(s) used to solve structure: SHELXT (Sheldrick, 2015a); program(s) used to refine structure: SHELXL2018/3 (Sheldrick, 2015b); molecular graphics: XP in SHELXTL (Sheldrick, 2008); software used to prepare material for publication: SHELX (Sheldrick, 2008), CIFFIX (Parkin, 2013), and publCIF (Westrip, 2010).

4,15-Dimethyl-7,12-diazoniatricyclo[10.4.0.0 $\left.0^{2,7}\right]$ hexadeca-1(12),2,4,6,13,15-hexaene dibromide monohydrate

\section{Crystal data}

$\mathrm{C}_{16} \mathrm{H}_{20} \mathrm{~N}_{2}{ }^{2+} \cdot 2\left(\mathrm{Br}^{-}\right) \cdot \mathrm{H}_{2} \mathrm{O}$

$M_{r}=418.17$

Monoclinic, $P 2{ }_{1} / n$

$a=7.6402(2) \AA$

$b=13.7578(3) \AA$

$c=16.7691(3) \AA$

$\beta=101.162(1)^{\circ}$

$V=1729.30(7) \AA^{3}$

$Z=4$

\section{Data collection}

Bruker D8 Venture dual source diffractometer

Radiation source: microsource

Detector resolution: 7.41 pixels $\mathrm{mm}^{-1}$

$\varphi$ and $\omega$ scans

Absorption correction: multi-scan

(SADABS; Krause et al., 2015)

$T_{\min }=0.562, T_{\max }=0.746$

\section{Refinement}

Refinement on $F^{2}$

Least-squares matrix: full

$R\left[F^{2}>2 \sigma\left(F^{2}\right)\right]=0.020$

$w R\left(F^{2}\right)=0.043$

$S=1.06$

3959 reflections

198 parameters

1 restraint

Primary atom site location: structure-invariant direct methods
$F(000)=840$

$D_{\mathrm{x}}=1.606 \mathrm{Mg} \mathrm{m}^{-3}$

Mo $K \alpha$ radiation, $\lambda=0.71073 \AA$

Cell parameters from 9914 reflections

$\theta=2.8-27.5^{\circ}$

$\mu=4.69 \mathrm{~mm}^{-1}$

$T=90 \mathrm{~K}$

Irregular shard, pink

$0.16 \times 0.12 \times 0.07 \mathrm{~mm}$

26025 measured reflections

3959 independent reflections

3527 reflections with $I>2 \sigma(I)$

$R_{\text {int }}=0.029$

$\theta_{\max }=27.5^{\circ}, \theta_{\min }=2.5^{\circ}$

$h=-9 \rightarrow 9$

$k=-17 \rightarrow 17$

$l=-21 \rightarrow 21$

Secondary atom site location: difference Fourier map

Hydrogen site location: mixed

$\mathrm{H}$ atoms treated by a mixture of independent and constrained refinement

$w=1 /\left[\sigma^{2}\left(F_{\mathrm{o}}^{2}\right)+(0.0121 P)^{2}+1.4994 P\right]$

where $P=\left(F_{\mathrm{o}}^{2}+2 F_{\mathrm{c}}^{2}\right) / 3$

$(\Delta / \sigma)_{\max }=0.002$

$\Delta \rho_{\max }=0.38 \mathrm{e} \AA^{-3}$

$\Delta \rho_{\min }=-0.38$ e $\AA^{-3}$ 


\section{Special details}

Experimental. The crystal was mounted using polyisobutene oil on the tip of a fine glass fibre, which was fastened in a copper mounting pin with electrical solder. It was placed directly into the cold gas stream of a liquid-nitrogen based cryostat (Hope, 1994; Parkin \& Hope, 1998).

Diffraction data were collected with the crystal at $90 \mathrm{~K}$, which is standard practice in this laboratory for the majority of flash-cooled crystals.

Geometry. All s.u.s (except the s.u. in the dihedral angle between two 1.s. planes) are estimated using the full covariance matrix. The cell s.u.s are taken into account individually in the estimation of s.u.s in distances, angles and torsion angles; correlations between s.u.s in cell parameters are only used when they are defined by crystal symmetry. An approximate (isotropic) treatment of cell s.u.s is used for estimating s.u.s involving l.s. planes.

Refinement. Refinement progress was checked using Platon (Spek, 2009) and by an R-tensor (Parkin, 2000). The final model was further checked with the IUCr utility checkCIF.

Fractional atomic coordinates and isotropic or equivalent isotropic displacement parameters $\left(\AA^{2}\right)$

\begin{tabular}{|c|c|c|c|c|}
\hline & $x$ & $y$ & $z$ & $U_{\text {iso }} * / U_{\text {eq }}$ \\
\hline Br1 & $0.38758(2)$ & $0.69802(2)$ & $0.11426(2)$ & $0.01809(5)$ \\
\hline $\mathrm{Br} 2$ & $0.09621(2)$ & $0.58825(2)$ & $0.34885(2)$ & $0.01872(5)$ \\
\hline N1 & $0.54040(19)$ & $0.38619(10)$ & $0.23392(9)$ & $0.0157(3)$ \\
\hline $\mathrm{C} 1$ & $0.5310(2)$ & $0.34004(13)$ & $0.16231(11)$ & $0.0193(4)$ \\
\hline H1 & 0.470042 & 0.279632 & 0.153665 & $0.023 *$ \\
\hline $\mathrm{C} 2$ & $0.6074(2)$ & $0.37819(13)$ & $0.10161(11)$ & $0.0190(4)$ \\
\hline $\mathrm{H} 2$ & 0.598713 & 0.344145 & 0.051717 & $0.023^{*}$ \\
\hline $\mathrm{C} 3$ & $0.6973(2)$ & $0.46646(13)$ & 0.1128 (1) & $0.0164(3)$ \\
\hline $\mathrm{C} 4$ & $0.7082(2)$ & $0.51161(13)$ & $0.18795(10)$ & $0.0159(3)$ \\
\hline $\mathrm{H} 4$ & 0.771186 & 0.571265 & 0.198231 & $0.019 *$ \\
\hline $\mathrm{C} 5$ & $0.6300(2)$ & $0.47175(12)$ & $0.24753(10)$ & 0.0140 \\
\hline C6 & $0.4467(2)$ & $0.34092(13)$ & $0.29478(11)$ & $0.0188(4)$ \\
\hline H6A & 0.337285 & 0.307919 & 0.266189 & $0.023 *$ \\
\hline H6B & 0.410854 & 0.392247 & 0.329762 & $0.023 *$ \\
\hline $\mathrm{C} 7$ & $0.5666(2)$ & $0.26732(13)$ & $0.34768(12)$ & 0.0215 \\
\hline H7B & 0.489315 & 0.219545 & 0.368381 & $0.026^{*}$ \\
\hline H7A & 0.635324 & 0.231572 & 0.312750 & $0.026^{*}$ \\
\hline $\mathrm{C} 8$ & $0.7795(3)$ & $0.51217(14)$ & $0.04805(11)$ & $0.0232(4)$ \\
\hline H8A & 0.750594 & 0.473388 & -0.001783 & $0.035^{*}$ \\
\hline H8B & 0.909326 & 0.514930 & 0.066178 & $0.035 *$ \\
\hline $\mathrm{H} 8 \mathrm{C}$ & 0.732611 & 0.578163 & 0.037298 & $0.035^{*}$ \\
\hline $\mathrm{N} 1^{\prime}$ & $0.72247(18)$ & $0.4864(1)$ & $0.39609(8)$ & $0.0136(3)$ \\
\hline $\mathrm{C} 1^{\prime}$ & $0.7337(2)$ & $0.53707(13)$ & $0.46545(10)$ & $0.0172(4)$ \\
\hline $\mathrm{H} 1^{\prime}$ & 0.792782 & 0.508916 & 0.515149 & $0.021 *$ \\
\hline $\mathrm{C} 2^{\prime}$ & $0.6619(2)$ & $0.62861(13)$ & $0.46625(10)$ & 0.0170 \\
\hline $\mathrm{H} 2^{\prime}$ & 0.673762 & 0.663389 & 0.515955 & $0.020^{*}$ \\
\hline C $3^{\prime}$ & $0.5719(2)$ & $0.67031(13)$ & $0.39448(11)$ & $0.0161(3)$ \\
\hline $\mathrm{C} 4^{\prime}$ & $0.5608(2)$ & $0.61627(12)$ & $0.32318(10)$ & $0.0154(3)$ \\
\hline $\mathrm{H} 4^{\prime}$ & 0.500590 & 0.642672 & 0.272967 & $0.018^{*}$ \\
\hline $\mathrm{C} 5^{\prime}$ & $0.6360(2)$ & $0.52515(12)$ & $0.32479(10)$ & 0.0135 \\
\hline $\mathrm{C} 6^{\prime}$ & $0.8162(2)$ & $0.39082(12)$ & $0.40077(11)$ & $0.0169(4)$ \\
\hline H6A' & 0.925433 & 0.393784 & 0.443492 & $0.020 *$ \\
\hline $\mathrm{H}^{\prime} \mathrm{B}^{\prime}$ & 0.852567 & 0.377516 & 0.348290 & $0.020^{*}$ \\
\hline
\end{tabular}




$\begin{array}{lllll}\mathrm{C} 7^{\prime} & 0.6976(2) & 0.30844(13) & 0.41992(11) & 0.0198(4) \\ \mathrm{H}^{\prime} \mathrm{A}^{\prime} & 0.629120 & 0.332138 & 0.460449 & 0.024^{*} \\ {\mathrm{H} 7 \mathrm{~B}^{\prime}}^{\mathrm{C}} & 0.775237 & 0.254877 & 0.445511 & 0.024^{*} \\ \mathrm{C}^{\prime} & 0.4859(2) & 0.76805(13) & 0.39343(12) & 0.0210(4) \\ \mathrm{H}^{\prime} \mathrm{A}^{\prime} & 0.500384 & 0.803271 & 0.344334 & 0.031^{*} \\ \mathrm{H} 8 \mathrm{~B}^{\prime} & 0.542276 & 0.804908 & 0.441597 & 0.031^{*} \\ \mathrm{H} 8 \mathrm{C}^{\prime} & 0.358509 & 0.760037 & 0.393689 & 0.031^{*} \\ \mathrm{O} 1 \mathrm{~W} & 0.1964(2) & 0.49717(11) & 0.17678(9) & 0.0297(3) \\ \mathrm{H} 1 \mathrm{~W} & 0.240(3) & 0.5445(16) & 0.1598(16) & 0.044^{*} \\ \mathrm{H} 2 \mathrm{~W} & 0.168(3) & 0.5155(19) & 0.2183(13) & 0.044^{*}\end{array}$

Atomic displacement parameters $\left(\AA^{2}\right)$

\begin{tabular}{lllllll}
\hline & $U^{11}$ & $U^{22}$ & $U^{33}$ & $U^{12}$ & $U^{13}$ & $U^{23}$ \\
\hline $\mathrm{Br} 1$ & $0.01962(9)$ & $0.02036(9)$ & $0.01455(8)$ & $0.00295(7)$ & $0.00397(6)$ & $0.00357(7)$ \\
$\mathrm{Br} 2$ & $0.01603(9)$ & $0.01993(9)$ & $0.01935(9)$ & $-0.00218(7)$ & $0.00129(6)$ & $0.00533(7)$ \\
$\mathrm{N} 1$ & $0.0134(7)$ & $0.0157(7)$ & $0.0178(7)$ & $-0.0010(6)$ & $0.0022(6)$ & $-0.0013(6)$ \\
$\mathrm{C} 1$ & $0.0155(8)$ & $0.0185(9)$ & $0.0229(9)$ & $-0.0014(7)$ & $0.0012(7)$ & $-0.0065(7)$ \\
$\mathrm{C} 2$ & $0.0166(8)$ & $0.0215(9)$ & $0.0181(8)$ & $0.0020(7)$ & $0.0012(7)$ & $-0.0056(7)$ \\
$\mathrm{C} 3$ & $0.0146(8)$ & $0.0189(9)$ & $0.0153(8)$ & $0.0046(7)$ & $0.0020(6)$ & $0.0001(7)$ \\
$\mathrm{C} 4$ & $0.0158(8)$ & $0.0140(8)$ & $0.0173(8)$ & $0.0006(6)$ & $0.0017(6)$ & $0.0005(7)$ \\
$\mathrm{C} 5$ & $0.0110(7)$ & $0.0144(8)$ & $0.0157(8)$ & $0.0020(6)$ & $0.0004(6)$ & $-0.0005(7)$ \\
$\mathrm{C} 6$ & $0.0147(8)$ & $0.0205(9)$ & $0.0220(9)$ & $-0.0043(7)$ & $0.0054(7)$ & $0.0003(7)$ \\
$\mathrm{C} 7$ & $0.0199(9)$ & $0.0166(9)$ & $0.0288(10)$ & $-0.0027(7)$ & $0.0064(8)$ & $0.0033(8)$ \\
$\mathrm{C} 8$ & $0.028(1)$ & $0.0254(10)$ & $0.0170(8)$ & $0.0006(8)$ & $0.0064(7)$ & $0.0000(8)$ \\
$\mathrm{N} 1^{\prime}$ & $0.0117(7)$ & $0.0138(7)$ & $0.0148(7)$ & $0.0000(5)$ & $0.0018(5)$ & $0.0018(6)$ \\
$\mathrm{C} 1^{\prime}$ & $0.0135(8)$ & $0.0234(9)$ & $0.0138(8)$ & $-0.0030(7)$ & $0.0005(6)$ & $0.0008(7)$ \\
$\mathrm{C} 2^{\prime}$ & $0.0153(8)$ & $0.0218(9)$ & $0.0142(8)$ & $-0.0034(7)$ & $0.0037(6)$ & $-0.0048(7)$ \\
$\mathrm{C} 3^{\prime}$ & $0.0111(8)$ & $0.0164(8)$ & $0.0213(9)$ & $-0.0035(6)$ & $0.0045(7)$ & $-0.0017(7)$ \\
$\mathrm{C}^{\prime}$ & $0.0130(8)$ & $0.0175(8)$ & $0.0153(8)$ & $-0.0009(6)$ & $0.0017(6)$ & $0.0013(7)$ \\
$\mathrm{C}^{\prime}$ & $0.0110(7)$ & $0.0151(8)$ & $0.0143(8)$ & $-0.0025(6)$ & $0.0021(6)$ & $0.0002(7)$ \\
$\mathrm{C} 6^{\prime}$ & $0.0125(8)$ & $0.0157(8)$ & $0.0213(9)$ & $0.0027(6)$ & $0.0006(7)$ & $0.0032(7)$ \\
$\mathrm{C}^{\prime}$ & $0.0164(8)$ & $0.0184(9)$ & $0.0246(9)$ & $0.0016(7)$ & $0.0044(7)$ & $0.0068(7)$ \\
$\mathrm{C}^{\prime}$ & $0.0194(9)$ & $0.0172(9)$ & $0.0266(9)$ & $-0.0003(7)$ & $0.0053(7)$ & $-0.0036(8)$ \\
$\mathrm{O} 1 \mathrm{~W}^{\prime}$ & $0.0309(8)$ & $0.0252(8)$ & $0.0342(8)$ & $-0.0016(6)$ & $0.0096(6)$ & $-0.0014(7)$ \\
& & & & & & \\
\hline
\end{tabular}

Geometric parameters $\left(A,{ }^{\circ}\right)$

\begin{tabular}{llll}
\hline $\mathrm{N} 1-\mathrm{C} 1$ & $1.348(2)$ & $\mathrm{N} 1^{\prime}-\mathrm{C} 1^{\prime}$ & $1.344(2)$ \\
$\mathrm{N} 1-\mathrm{C} 5$ & $1.359(2)$ & $\mathrm{N} 1^{\prime}-\mathrm{C} 5^{\prime}$ & $1.358(2)$ \\
$\mathrm{N} 1-\mathrm{C} 6$ & $1.491(2)$ & $\mathrm{N} 1^{\prime}-\mathrm{C} 6^{\prime}$ & $1.492(2)$ \\
$\mathrm{C} 1-\mathrm{C} 2$ & $1.372(3)$ & $\mathrm{C} 1^{\prime}-\mathrm{C} 2^{\prime}$ & $1.375(2)$ \\
$\mathrm{C} 1-\mathrm{H} 1$ & 0.9500 & $\mathrm{C} 1^{\prime}-\mathrm{H} 1^{\prime}$ & 0.9500 \\
$\mathrm{C} 2-\mathrm{C} 3$ & $1.390(2)$ & $\mathrm{C} 2^{\prime}-\mathrm{C} 3^{\prime}$ & $1.389(2)$ \\
$\mathrm{C} 2-\mathrm{H} 2$ & 0.9500 & $\mathrm{C} 2^{\prime}-\mathrm{H} 2^{\prime}$ & 0.9500 \\
$\mathrm{C} 3-\mathrm{C} 4$ & $1.393(2)$ & $\mathrm{C} 3^{\prime}-\mathrm{C} 4^{\prime}$ & $1.396(2)$ \\
$\mathrm{C} 3-\mathrm{C} 8$ & $1.494(2)$ & $\mathrm{C} 3^{\prime}-\mathrm{C} 8^{\prime}$ & $1.495(2)$ \\
$\mathrm{C} 4-\mathrm{C} 5$ & $1.374(2)$ & $\mathrm{C}^{\prime}-\mathrm{C} 5^{\prime}$ & $1.377(2)$
\end{tabular}




\begin{tabular}{|c|c|c|c|}
\hline $\mathrm{C} 4-\mathrm{H} 4$ & 0.9500 & $\mathrm{C} 4^{\prime}-\mathrm{H} 4^{\prime}$ & 0.9500 \\
\hline $\mathrm{C} 5-\mathrm{C}^{\prime}$ & $1.482(2)$ & $\mathrm{C} 6^{\prime}-\mathrm{C} 7^{\prime}$ & $1.523(2)$ \\
\hline $\mathrm{C} 6-\mathrm{C} 7$ & $1.528(3)$ & $\mathrm{C} 6^{\prime}-\mathrm{H} 6 \mathrm{~A}^{\prime}$ & 0.9900 \\
\hline C6-H6A & 0.9900 & $\mathrm{C} 6^{\prime}-\mathrm{H}_{6} \mathrm{~B}^{\prime}$ & 0.9900 \\
\hline C6-H6B & 0.9900 & $\mathrm{C}^{\prime}-\mathrm{H} 7 \mathrm{~A}^{\prime}$ & 0.9900 \\
\hline $\mathrm{C} 7-\mathrm{C} 7^{\prime}$ & $1.523(3)$ & $\mathrm{C}^{\prime}-\mathrm{H} 7 \mathrm{~B}^{\prime}$ & 0.9900 \\
\hline C7-H7B & 0.9900 & $\mathrm{C} 8^{\prime}-\mathrm{H}_{8 \mathrm{~A}^{\prime}}$ & 0.9800 \\
\hline C7-H7A & 0.9900 & $\mathrm{C} 8^{\prime}-\mathrm{H} 8 \mathrm{~B}^{\prime}$ & 0.9800 \\
\hline $\mathrm{C} 8-\mathrm{H} 8 \mathrm{~A}$ & 0.9800 & $\mathrm{C} 8^{\prime}-\mathrm{H} 8 \mathrm{C}^{\prime}$ & 0.9800 \\
\hline $\mathrm{C} 8-\mathrm{H} 8 \mathrm{~B}$ & 0.9800 & $\mathrm{O} 1 \mathrm{~W}-\mathrm{H} 1 \mathrm{~W}$ & 0.809 (19) \\
\hline $\mathrm{C} 8-\mathrm{H} 8 \mathrm{C}$ & 0.9800 & $\mathrm{O} 1 \mathrm{~W}-\mathrm{H} 2 \mathrm{~W}$ & 0.807 (19) \\
\hline $\mathrm{C} 1-\mathrm{N} 1-\mathrm{C} 5$ & $119.74(15)$ & $\mathrm{C} 1^{\prime}-\mathrm{N} 1^{\prime}-\mathrm{C} 6^{\prime}$ & $117.50(14)$ \\
\hline $\mathrm{C} 1-\mathrm{N} 1-\mathrm{C} 6$ & $117.59(15)$ & $\mathrm{C} 5^{\prime}-\mathrm{N} 1^{\prime}-\mathrm{C} 6^{\prime}$ & $122.62(14)$ \\
\hline $\mathrm{C} 5-\mathrm{N} 1-\mathrm{C} 6$ & $122.66(14)$ & $\mathrm{N} 1^{\prime}-\mathrm{C} 1^{\prime}-\mathrm{C} 2^{\prime}$ & $121.64(16)$ \\
\hline $\mathrm{N} 1-\mathrm{C} 1-\mathrm{C} 2$ & $121.59(17)$ & $\mathrm{N} 1^{\prime}-\mathrm{C} 1^{\prime}-\mathrm{H} 1^{\prime}$ & 119.2 \\
\hline $\mathrm{N} 1-\mathrm{C} 1-\mathrm{H} 1$ & 119.2 & $\mathrm{C} 2^{\prime}-\mathrm{C} 1^{\prime}-\mathrm{H} 1^{\prime}$ & 119.2 \\
\hline $\mathrm{C} 2-\mathrm{C} 1-\mathrm{H} 1$ & 119.2 & $\mathrm{C} 1^{\prime}-\mathrm{C} 2^{\prime}-\mathrm{C} 3^{\prime}$ & $120.09(16)$ \\
\hline $\mathrm{C} 1-\mathrm{C} 2-\mathrm{C} 3$ & $120.29(16)$ & $\mathrm{C} 1^{\prime}-\mathrm{C} 2^{\prime}-\mathrm{H} 2^{\prime}$ & 120.0 \\
\hline $\mathrm{C} 1-\mathrm{C} 2-\mathrm{H} 2$ & 119.9 & $\mathrm{C} 3^{\prime}-\mathrm{C} 2^{\prime}-\mathrm{H} 2^{\prime}$ & 120.0 \\
\hline $\mathrm{C} 3-\mathrm{C} 2-\mathrm{H} 2$ & 119.9 & $\mathrm{C} 2^{\prime}-\mathrm{C} 3^{\prime}-\mathrm{C} 4^{\prime}$ & $117.37(16)$ \\
\hline $\mathrm{C} 2-\mathrm{C} 3-\mathrm{C} 4$ & $116.94(16)$ & $\mathrm{C} 2^{\prime}-\mathrm{C} 3^{\prime}-\mathrm{C} 8^{\prime}$ & $121.61(16)$ \\
\hline $\mathrm{C} 2-\mathrm{C} 3-\mathrm{C} 8$ & $122.41(16)$ & $\mathrm{C} 4^{\prime}-\mathrm{C} 3^{\prime}-\mathrm{C} 8^{\prime}$ & $121.00(16)$ \\
\hline $\mathrm{C} 4-\mathrm{C} 3-\mathrm{C} 8$ & $120.65(16)$ & $\mathrm{C} 5^{\prime}-\mathrm{C} 4^{\prime}-\mathrm{C} 3^{\prime}$ & $120.79(16)$ \\
\hline $\mathrm{C} 5-\mathrm{C} 4-\mathrm{C} 3$ & $121.45(16)$ & $\mathrm{C} 5^{\prime}-\mathrm{C} 4^{\prime}-\mathrm{H} 4^{\prime}$ & 119.6 \\
\hline $\mathrm{C} 5-\mathrm{C} 4-\mathrm{H} 4$ & 119.3 & $\mathrm{C} 3^{\prime}-\mathrm{C} 4^{\prime}-\mathrm{H} 4^{\prime}$ & 119.6 \\
\hline $\mathrm{C} 3-\mathrm{C} 4-\mathrm{H} 4$ & 119.3 & $\mathrm{~N} 1^{\prime}-\mathrm{C} 5^{\prime}-\mathrm{C} 4^{\prime}$ & $120.31(15)$ \\
\hline $\mathrm{N} 1-\mathrm{C} 5-\mathrm{C} 4$ & $119.97(15)$ & $\mathrm{N} 1{ }^{\prime}-\mathrm{C} 5^{\prime}-\mathrm{C} 5$ & $120.15(15)$ \\
\hline $\mathrm{N} 1-\mathrm{C} 5-\mathrm{C} 5^{\prime}$ & $120.37(15)$ & $\mathrm{C} 4^{\prime}-\mathrm{C} 5^{\prime}-\mathrm{C} 5$ & $119.46(15)$ \\
\hline $\mathrm{C} 4-\mathrm{C} 5-\mathrm{C} 5^{\prime}$ & $119.58(15)$ & $\mathrm{N} 1^{\prime}-\mathrm{C} 6^{\prime}-\mathrm{C} 7^{\prime}$ & $111.60(14)$ \\
\hline $\mathrm{N} 1-\mathrm{C} 6-\mathrm{C} 7$ & $111.16(14)$ & $\mathrm{N} 1^{\prime}-\mathrm{C} 6^{\prime}-\mathrm{H} 6 \mathrm{~A}^{\prime}$ & 109.3 \\
\hline $\mathrm{N} 1-\mathrm{C} 6-\mathrm{H} 6 \mathrm{~A}$ & 109.4 & $\mathrm{C} 7^{\prime}-\mathrm{C} 6^{\prime}-\mathrm{H}^{\prime} \mathrm{A}^{\prime}$ & 109.3 \\
\hline $\mathrm{C} 7-\mathrm{C} 6-\mathrm{H} 6 \mathrm{~A}$ & 109.4 & $\mathrm{~N} 1^{\prime}-\mathrm{C} 6^{\prime}-\mathrm{H} 6 \mathrm{~B}^{\prime}$ & 109.3 \\
\hline $\mathrm{N} 1-\mathrm{C} 6-\mathrm{H} 6 \mathrm{~B}$ & 109.4 & $\mathrm{C} 7^{\prime}-\mathrm{C} 6^{\prime}-\mathrm{H} 6 \mathrm{~B}^{\prime}$ & 109.3 \\
\hline $\mathrm{C} 7-\mathrm{C} 6-\mathrm{H} 6 \mathrm{~B}$ & 109.4 & $\mathrm{H}^{6} \mathrm{~A}^{\prime}-\mathrm{C} 6^{\prime}-\mathrm{H}^{\prime} \mathrm{B}^{\prime}$ & 108.0 \\
\hline $\mathrm{H} 6 \mathrm{~A}-\mathrm{C} 6-\mathrm{H} 6 \mathrm{~B}$ & 108.0 & $\mathrm{C} 6^{\prime}-\mathrm{C} 7^{\prime}-\mathrm{C} 7$ & $115.78(15)$ \\
\hline $\mathrm{C} 7{ }^{\prime}-\mathrm{C} 7-\mathrm{C} 6$ & $116.31(15)$ & $\mathrm{C} 6^{\prime}-\mathrm{C} 7^{\prime}-\mathrm{H}_{7} \mathrm{~A}^{\prime}$ & 108.3 \\
\hline $\mathrm{C} 7^{\prime}-\mathrm{C} 7-\mathrm{H} 7 \mathrm{~B}$ & 108.2 & $\mathrm{C} 7-\mathrm{C}^{\prime}-\mathrm{H}^{\prime} \mathrm{A}^{\prime}$ & 108.3 \\
\hline $\mathrm{C} 6-\mathrm{C} 7-\mathrm{H} 7 \mathrm{~B}$ & 108.2 & $\mathrm{C} 6^{\prime}-\mathrm{C} 7^{\prime}-\mathrm{H} 7 \mathrm{~B}^{\prime}$ & 108.3 \\
\hline $\mathrm{C}^{\prime}-\mathrm{C} 7-\mathrm{H} 7 \mathrm{~A}$ & 108.2 & $\mathrm{C} 7-\mathrm{C}^{\prime}-\mathrm{H}^{\prime} \mathrm{B}^{\prime}$ & 108.3 \\
\hline $\mathrm{C} 6-\mathrm{C} 7-\mathrm{H} 7 \mathrm{~A}$ & 108.2 & $\mathrm{H}^{\prime} \mathrm{A}^{\prime}-\mathrm{C}^{\prime}-\mathrm{H}^{\prime} \mathrm{B}^{\prime}$ & 107.4 \\
\hline $\mathrm{H} 7 \mathrm{~B}-\mathrm{C} 7-\mathrm{H} 7 \mathrm{~A}$ & 107.4 & $\mathrm{C}^{\prime}-\mathrm{C} 8^{\prime}-\mathrm{H} 8 \mathrm{~A}^{\prime}$ & 109.5 \\
\hline $\mathrm{C} 3-\mathrm{C} 8-\mathrm{H} 8 \mathrm{~A}$ & 109.5 & $\mathrm{C} 3^{\prime}-\mathrm{C} 8^{\prime}-\mathrm{H} 8 \mathrm{~B}^{\prime}$ & 109.5 \\
\hline $\mathrm{C} 3-\mathrm{C} 8-\mathrm{H} 8 \mathrm{~B}$ & 109.5 & $\mathrm{H}^{2} \mathrm{~A}^{\prime}-\mathrm{C} 8^{\prime}-\mathrm{H}^{\prime} \mathrm{B}^{\prime}$ & 109.5 \\
\hline $\mathrm{H} 8 \mathrm{~A}-\mathrm{C} 8-\mathrm{H} 8 \mathrm{~B}$ & 109.5 & $\mathrm{C} 3^{\prime}-\mathrm{C} 8^{\prime}-\mathrm{H} 8 \mathrm{C}^{\prime}$ & 109.5 \\
\hline $\mathrm{C} 3-\mathrm{C} 8-\mathrm{H} 8 \mathrm{C}$ & 109.5 & $\mathrm{H} 8 \mathrm{~A}^{\prime}-\mathrm{C} 8^{\prime}-\mathrm{H} 8 \mathrm{C}^{\prime}$ & 109.5 \\
\hline $\mathrm{H} 8 \mathrm{~A}-\mathrm{C} 8-\mathrm{H} 8 \mathrm{C}$ & 109.5 & $\mathrm{H} 8 \mathrm{~B}^{\prime}-\mathrm{C} 8^{\prime}-\mathrm{H} 8 \mathrm{C}^{\prime}$ & 109.5 \\
\hline $\mathrm{H} 8 \mathrm{~B}-\mathrm{C} 8-\mathrm{H} 8 \mathrm{C}$ & 109.5 & $\mathrm{H} 1 \mathrm{~W}-\mathrm{O} 1 \mathrm{~W}-\mathrm{H} 2 \mathrm{~W}$ & $104(3)$ \\
\hline
\end{tabular}


$\mathrm{C} 1^{\prime}-\mathrm{N} 1^{\prime}-\mathrm{C} 5^{\prime}$

$\mathrm{C} 5-\mathrm{N} 1-\mathrm{C} 1-\mathrm{C} 2$

$\mathrm{C} 6-\mathrm{N} 1-\mathrm{C} 1-\mathrm{C} 2$

$\mathrm{N} 1-\mathrm{C} 1-\mathrm{C} 2-\mathrm{C} 3$

$\mathrm{C} 1-\mathrm{C} 2-\mathrm{C} 3-\mathrm{C} 4$

$\mathrm{C} 1-\mathrm{C} 2-\mathrm{C} 3-\mathrm{C} 8$

$\mathrm{C} 2-\mathrm{C} 3-\mathrm{C} 4-\mathrm{C} 5$

$\mathrm{C} 8-\mathrm{C} 3-\mathrm{C} 4-\mathrm{C} 5$

$\mathrm{C} 1-\mathrm{N} 1-\mathrm{C} 5-\mathrm{C} 4$

$\mathrm{C} 6-\mathrm{N} 1-\mathrm{C} 5-\mathrm{C} 4$

$\mathrm{C} 1-\mathrm{N} 1-\mathrm{C} 5-\mathrm{C}^{\prime}$

C6-N1- 5 - $\mathrm{C}^{\prime}$

$\mathrm{C} 3-\mathrm{C} 4-\mathrm{C} 5-\mathrm{N} 1$

$\mathrm{C} 3-\mathrm{C} 4-\mathrm{C} 5-\mathrm{C} 5^{\prime}$

$\mathrm{C} 1-\mathrm{N} 1-\mathrm{C} 6-\mathrm{C} 7$

$\mathrm{C} 5-\mathrm{N} 1-\mathrm{C} 6-\mathrm{C} 7$

$\mathrm{N} 1-\mathrm{C} 6-\mathrm{C} 7-\mathrm{C}^{\prime}$

$\mathrm{C} 5^{\prime}-\mathrm{N} 1^{\prime}-\mathrm{C} 1^{\prime}-\mathrm{C} 2^{\prime}$

$\mathrm{C} 6^{\prime}-\mathrm{N} 1^{\prime}-\mathrm{C}^{\prime}-\mathrm{C} 2^{\prime}$

$\mathrm{N} 1^{\prime}-\mathrm{C}^{\prime}-\mathrm{C} 2^{\prime}-\mathrm{C} 3^{\prime}$
$119.79(15)$

$-1.2(3)$

$177.51(16)$

$0.0(3)$

$1.3(2)$

$-178.70(17)$

$-1.5(2)$

$178.50(16)$

$1.0(2)$

$-177.65(15)$

$177.79(15)$

$-0.8(2)$

0.4 (3)

$-176.45(15)$

87.25 (19)

$-94.09(19)$

$83.16(19)$

$-1.0(2)$

$175.61(15)$

$1.3(3)$

Hydrogen-bond geometry $\left(\AA,{ }^{o}\right)$

\begin{tabular}{|c|c|c|c|c|}
\hline$D-\mathrm{H} \cdots A$ & $D-\mathrm{H}$ & $\mathrm{H} \cdots A$ & $D \cdots A$ & $D-\mathrm{H} \cdots A$ \\
\hline $\mathrm{C} 1-\mathrm{H} 1 \cdots \mathrm{Br} 2^{\mathrm{i}}$ & 0.95 & 2.68 & $3.5929(18)$ & 161 \\
\hline $\mathrm{C} 2-\mathrm{H} 2 \cdots \mathrm{Br} 1^{\mathrm{ii}}$ & 0.95 & 2.86 & $3.7762(18)$ & 161 \\
\hline $\mathrm{C} 7-\mathrm{H} 7 B \cdots \mathrm{Br} 1^{\mathrm{i}}$ & 0.99 & 2.96 & $3.7700(19)$ & 139 \\
\hline $\mathrm{C} 1^{\prime}-\mathrm{H} 1^{\prime} \cdots \mathrm{Br} 2^{\mathrm{iii}}$ & 0.95 & 2.64 & $3.5765(17)$ & 170 \\
\hline $\mathrm{C} 2^{\prime}-\mathrm{H} 2^{\prime} \cdots \mathrm{Br} 1^{\text {iv }}$ & 0.95 & 2.82 & $3.6285(17)$ & 143 \\
\hline $\mathrm{C} 4^{\prime}-\mathrm{H} 4^{\prime} \cdots \mathrm{Br} 1$ & 0.95 & 2.74 & $3.6735(17)$ & 167 \\
\hline $\mathrm{C} 7^{\prime}-\mathrm{H} 7 B^{\prime} \cdots \mathrm{Br}^{\mathrm{v}}$ & 0.99 & 3.04 & $3.6581(18)$ & 122 \\
\hline $\mathrm{O} 1 W-\mathrm{H} 1 W \cdots \mathrm{Br} 1$ & $0.81(2)$ & $2.58(2)$ & $3.3856(15)$ & $177(3)$ \\
\hline $\mathrm{O} 1 W-\mathrm{H} 2 W \cdots \mathrm{Br} 2$ & $0.81(2)$ & $2.56(2)$ & $3.3670(15)$ & $175(3)$ \\
\hline
\end{tabular}

Symmetry codes: (i) $-x+1 / 2, y-1 / 2,-z+1 / 2$; (ii) $-x+1,-y+1,-z$; (iii) $-x+1,-y+1,-z+1$; (iv) $x+1 / 2,-y+3 / 2, z+1 / 2$; (v) $-x+3 / 2, y-1 / 2,-z+1 / 2$. 